\title{
TELAAHAN ULANG \\ CIRI-CIRI MANUSIA INDONESIA
}

\author{
Oleh \\ Andin H. Taryoto \\ Dosen Jurusan Penyuluhan Perikanan Sekolah Tinggi Perikanan
}

\begin{abstract}
ABSTRAK
Secara kontroversial pada tahun 1977 Mochtar Lubis menyebut manusia Indonesia sebagai Munafik, enggan bertangggungjawab atas perbuatannya, feodal, percaya takhyul, artistik, dan lemah karakternya . Setelah waktu berjalan lebih dari 30 tahun, dinilai perlu untuk mengkaji apakah benar ciri-ciri manusia Indonesia adalah seperti itu.

Hasil kajian menunjukkan bahwa telah terjadi pergeseran ciri-ciri manusia Indonesia, meskipun masih saja mengarah pada disebutkannya ciri-ciri yang lebih bersifat negatif. Munculnya ciri Brutal, sementara ciri Ksatria tidak dipilih oleh satupun responden, menunjukkan bahwa ciri-ciri kehidupan manusia Indonesia cukup memprihatinkan. Diperlukan langkah-langkah khusus untuk mengembalikan citra kesopanan dan kesantunan manusia Indonesia.

Pihak-pihak yang terkait dengan kegiatan penyuluhan perikanan perlu secara baik mengintegrasikan pemahaman tentang ciri-ciri manusia Indonesia didalam kegiatan penyuluhan yang dilakukan. Dengan demikian penyuluhan diharapkan dapat berjalan lebih efektif.
\end{abstract}

Kata-kata kunci: ciri-ciri manusia Indonesia, perubahan ciri-ciri, integrasi ciri-ciri manusia Indonesia pada kegiatan penyuluhan perikanan

\section{PENDAHULUAN}

\section{Latar Belakang}

Pengembangan sumberdaya manusia telah menjadi pokok bahasan yang tidak hanya berada di aras lokal dan nasional, tetapi telah menjadi issue global. Konsep MDG (Millennium Development Goals) secara eksplisit menyatakan pengembangan sumberdaya manusia ini dalam butir-butir tujuan yang ditargetkan dicapai pada aras global (United Nations, 2010). Berbagai lembaga berkepentingan dengan pokok bahasan in, sehingga PBB melalui lembaga-lembaga yang bernaung dibawahnya secara khusus memberikan perhatian pada aspek pengembangan sumberdaya manusia 
ini.

Sejumlah lembaga dan institusi di Indonesia secara eksplisit menjadikan tema pengembangan sumberdaya manusia sebagai cakupan bidang kerja dan fokus perhatiannya. Kementrian Tenaga Kerja dan Transmigrasi, misalnya, memiliki sejumlah lembaga yang bertugas khusus dalam kerangka pengembangan sumberdaya manusia ini (Suparno, 200). Sejumlah lembaga swasta dan Lembaga Swadaya Masyarakat (LSM) tidak sedikit pula yang menjadikan pengembangan sumberdaya manusia sebagai tema dari bidang kerjanya.

Dari berbagai pokok bahasan tentang pengembangan sumberdaya manusia itu, salah satu topik yang dinilai perlu diperhatikan adalah yang terkait dengan penciri spesifik yang melekat pada individu manusianya sendiri. Dalam percaturan internasional, dikenal ungkapan-ungkapan yang menunjuk pada ciri-ciri spesifik itu. Orang Jepang, misalnya, dikenal sebagai pekerja keras yag ulet dan taat azas pada prinsip-prinsip hidup yang dianutnya. Orang China dikenal sebagai manusia yang memiliki jiwa bisnis dan hemat dalam mengatur keuangannya (Sutanto, 2007). Sementara itu, oranng India dikenal sebagai orang yang sangat gemar dan fasih berbicara (Sen, 2005), sehingga dengan ciri-ciri itu, mereka dapat bekerja pada berbagai bidang di seluruh penjuru dunia.

Secara "turun-temurun" selama in manusia Indonesia dikenal sebagai bangsa yang sopan santun, menghargai pendapat orang lain, dan murah senyum. Namun demikian, Noer (2010) menyatakan bahwa harus diakui nilai-nilai kesopanan dan kesantunan manusia Indonesia telah berangsur-angsur memudar. Dalam pada itu, berdasarkan hasil survei The Smiling Report 2009, Indonesia adalah negara paling murah senyum di dunia dengan skor $98 \%$. Siaran pers The Smiling Report dari AB Better Business berbasis di Swedia (8/4/2009) yang diterima situs detik.com (16/5/2009) juga menyebutkan bahwa skor terbaik ucapan salam yang juga diberikan kepada Indonesia ini terutama ditemukan dalam pelayanan pemerintah (94\%), meskipun dalam hal business to business (B2B) hanya mendapatkan skor 70\%. Sementara itu negara paling susah senyum adalah Pakistan dengan skor $44 \%$ dan terendah untuk memberikan salam adalah Maroko dengan skor 48\%. Swedia sendiri berada di rangking 24, dengan skor untuk murah senyum $77 \%$ dan salam $81 \%$.

Masyarakat Indonesia dengan demikian menjadi sangat terkejut saat Mochtar Lubis pada ceramahnya tanggal 6 April 1977 di Taman Ismail Marzuki Jakarta menyebutkan beberapa ciri Manusia Indonesia yang jauh dari bayangan berkonotasi positif (Lubis, 2008). Dalam ceramah yang disebutnya sebagai "Sebuah Pertanggungjawaban” itu, Lubis secara 
terbuka menyebutkan beberapa ciri dominan dari manusia Indonesia: (1) Munafik atau hipokrit, (2) enggan dan segan bertangggungjawab atas perbuatannya, (3) bersikap dan berperilaku feodal, (4) percaya takhyul, (5) artistik, dan (6) lemah watak atau karakternya (Oetama, dalam pengantar Lubis, 2008). Berbagai tanggapan dan komentar muncul terhadap pernyataan Mochtar Lubis tersebut, namun demikian Lubis tetap bertahan dengan pendapatnya (Lubis, 2008: 90-96).

Waktu telah berjalan lebih dari 30 tahun sejak pernyataan Lubis yang kontroversial tersebut. Tulisan ini dengan demikian ditujukan untuk mencoba menguji kembali, apakah ciri-ciri manusia Indonesia masih tetap seperti apa yang dinyatakan oleh Lubis, ataukah telah terjadi perubahan-perubahan secara mendasar.

\section{Tujuan}

Secara terinci, tujuan kajian in adalah:

1. Mendalami ciri-ciri manusia Indonesia seperti yang dinyatakan oleh Lubis (2008)

2. Mengetahui apakah telah terjadi perubahan ciri-ciri Manusia Indonesia setelah berselang lebih dari 30 tahun sejak pernyataan Lubis

Dengan mengetahui hal-hal tersebut, diharapkan dapat disusun langkah-langkah yang diperlukan untuk mengarahkan agar ciri-ciri manusia Indonesia terus berada dalam jalur yang positif. Secara spesifik, kajian diharapkan dapat menjadi salah satu bahan masukan bagi penyelenggaraan kegiatan penyuluhan perikanan di Indonesia.

\section{METODOLOGI}

\section{Kerangka Pemikiran}

Secara lugas dan terbuka Lubis (2008) pada tahun 1977 mengemukakan pandangannya mengenai ciri-ciri manusia Indonesia. Dengan secara terbuka juga Lubis menyampaikan argumentasinya mengenai ciri-ciri manusia Indonesia itu, terutama sehubungan dengan ciri-ciri yang dinilai tidak bernuansa positif. Tabel 1 . berikut meringkaskan pendapat Lubis yang cukup banyak memancing reaksi berbagai pihak itu.

Uraian Lubis dalam bukunya itu dinilai mencoba mengemukakan pandangannya secara obyektif, tanpa bermaksud menghakimi. Hal in setidaknya dapat dilihat dari 2 hal: pertama, Lubis menyatakan bahwa apa yang disampaikan semata-mata adalah sebuah pertanggungjabannya terhadap bangsa ini sebagai budayawan yang terpanggil untuk memberikan masukannya. Secara implisit Lubis menyampaikan harapan agar pendapatnya dapat menggugah pemikiran bangsa Indonesia untuk mau dan mampu melakukan introspeksi mandiri, untuk kepentingan bangsa ini dimasa depan. Kedua, secara berimbang sebenarnya Lubis 
juga menyampaikan bahwa cukup banyak juga ciri-ciri manusia Indonesia yang bersifat positif. Lemah lembut, sopan, penuh kasih sayang, murah senyum, adalah beberapa diantara ciri positif yang dikemukakannya. Namun Lubis lebih memberikan penekanan pada ciri-ciri yang dinilai perlu diperbaiki di masa depan, agar secara sistenatik bangsa in benar-benar menuju pencitraan bangsa yang memang dapat membawakan diri secara pantas di percaturan dunia. Hal ini terutama mengingat kala itu sudah terindikasikan bahwa pada masa mendatang jejaring interaksi yang bernuansa global akan menjadi hal yang tidak bisa dihindarkan adanya.

Salah satu hal yang mendapat kritikan tajam dari pengungkapan Lubis tentang ciri-ciri manusia Indonesia adalah adanya kelemahan dalam pengungkapan pernyataan Lubis, sehingga dikhawatirkan dapat mengundang salah persepsi dari mereka yang tidak memahami secara dalam pemikiran Lubis (Wirawan dalam Lubis, 2008: hal. 81). Secara tidak langsung Wirawan menyatakan bahwa pernyataan-pernyataan Lubis hanyalah didasarkan pada pengamatan pribadi, dan tidak didasarkan pada suatu studi atau penelitian yang khusus dilakukan untuk itu.

$$
\text { Hanifah (Lubis, 2008: 119-133) }
$$

menyebutkan bahwa pendapat Lubis sebenarnya telah diindikasikan oleh beberapa pengamat pada masa-masa sebelumnya. Dengan pengungkapan Lubis tersebut, Hanifah bahkan menyebut Lubis sebagai “dokter masyarakat” yang telah berhasil melakukan diagnosa terhadap penyakit-penyakit yang diidap manusia Indonesia. Masalahnya adalah tinggal pada mencari 'obat' yang mujarab bagi penyakit-penyakit tersebut; seyogyanya 'obat' dicari dari dalam tubuh manusia Indonesia sendiri, tidak harus mencari resep-resep dari luar. Diagnosis yang senada juga disampaikan oleh Husaini (2010) yang menyitir pendapat Hamka:

“Banyak guru, dokter, hakim, insinyur, banyak orang yang bukunya satu gudang dan diplomanya segulung besar, tiba dalam masyarakat menjadi "mati", sebab dia bukan orang masyarakat. Hidupnya hanya mementingkan dirinya, diplomanya hanya untuk mencari harta, hatinya sudah seperti batu, tidak mampunyai cita-cita, lain dari pada kesenangan dirinya. Pribadinya tidak kuat. Dia bergerak bukan karena dorongan jiwa dan akal. Kepandaiannya yang banyak itu kerap kali menimbulkan takutnya. Bukan menimbulkan keberaniannya memasuki lapangan hidup.” 
Tabel 1. Ciri-ciri Manusia Indonesia (Lubis, 2008)

\begin{tabular}{|c|c|}
\hline No. & CIRI-CIRI \\
\hline 1. & $\begin{array}{l}\text { HIPOKRITIS alias MUNAFIK. Berpura-pura, lain di muka, lain di belakang, } \\
\text { terjadi karena mereka dipaksa oleh kekuatan-kekuatan dari luar untuk } \\
\text { menyembunyikan apa yang sebenarnya dirasakannya atau dipikirkannya atau pun } \\
\text { yang sebenarnya dikehendakinya, karena takut akan mendapat ganjaran yang } \\
\text { membawa bencana bagi dirinya.” }\end{array}$ \\
\hline 2. & $\begin{array}{l}\text { SEGAN DAN ENGGAN BERTANGGUNGJAWAB atas perbuatannya, } \\
\text { putusannya, kelakukannya, pikirannya, dan sebagainya. "Bukan saya” adalah } \\
\text { kalimat yang cukup populer pula di mulut manusia Indonesia. }\end{array}$ \\
\hline 3. & $\begin{array}{l}\text { FEODAL. Meskipun salah satu tujuan revolusi kemerdekaan Indonesia ialah juga } \\
\text { untuk membebaskan manusia Indonesia dari feodalisme, tetapi feodalisme dalam } \\
\text { bentuk-bentuk baru makin berkembang dalam diri dan masyarakat manusia } \\
\text { Indonesia. }\end{array}$ \\
\hline 4. & $\begin{array}{l}\text { PERCAYA PADA TAKHAYUL. Apabila dulu manusia Indonesia percaya pada } \\
\text { kekuatan pohon, keris, gunung, maka saat in manusia Indonesia membuat mantera } \\
\text { dan semboyan baru, jimat-jimat baru: Tritura, Ampera, Orde Baru, the rule of law, } \\
\text { pemberantasan korupsi, kemakmuran yang merata dan adil, Insan } \\
\text { Pembangunan..... Manusia Indonesia sangat mudah cenderung percaya pada } \\
\text { menara dan semboyan dan lambang yang dibuatnya sendiri. }\end{array}$ \\
\hline 5. & $\begin{array}{l}\text { ARTISTIK. Manusia Indonesia dekat dengan alam. Dia hidup lebih banyak } \\
\text { dengan naluri, dengan perasaannya, dengan perasaan-perasaan sensualnya, dan } \\
\text { semuanya in mengembangkan daya artistik yang besar dalam dirinya yang } \\
\text { dituangkan dalam segala rupa ciptaan artistik. Ciri in adalah yang paling menarik } \\
\text { dan mempersonakan, dan merupakan sumber dan tumpuan harapan bagi hari depan } \\
\text { manusia Indonesia }\end{array}$ \\
\hline 6. & $\begin{array}{l}\text { BERWATAK LEMAH; karakter kurang kuat. Manusia Indonesia kurang kuat } \\
\text { mempertahankan atau memperjuangkan keyakinannya. Dia mudah, apalagi jika } \\
\text { dipaksa, dan demi untuk “survive”, bersedia mengubah keyakinannya. Gejala } \\
\text { pelacuran intelektual amat mudah terjadi pada manusia Indonesia. }\end{array}$ \\
\hline
\end{tabular}

Terkait dengan pernyatan Lubis, Hal in dinilainya akan dapat menjadi modal Setiawan (2008) justru menemukan bahwa bagi manusia Indonesia untuk tampil di banyak manusia Indonesia yang berkualitas gelanggang ataupun percaturan internasional. tinggi, terutama mereka yang mendalami Meskipun demikian, Setiawan mengakui bidang-bidang teknologi, sosial, dan budaya. bahwa mental "main Terabas” yang masih 
menjadi ciri beberapa manusia Indonesia haruslah dapat dikendalikan atau bahkan dihilangkan. Hal in sejalan dengan pemikiran Prayoto (2004) yang menyatakan bahwa ingkat kesejahteraan suatu bangsa tampaknya sangat tergantung pada kemampuannya menguasai dan memanfaatkan ilmu pengetahuan dan teknologi dan hal ini ditentukan oleh kualitas sumber daya manusia. Ciri-ciri manusia tentulah terkait erat dengan yang dimaksud sebagai kualitas sumberdaya manusia oleh Setiawan ini.

Menurut Januar (2010), terdapat 2 faktor utama yang mempengaruhi perkembangan individu: faktor Keturunan dan faktor Lingkungan (Keluarga, Sekolah atau pendidikan, Teman Sebaya atau teman bergaul, dan Masyarakat). Kedua faktor menghasilkan resultan hasil yang kemudian muncul menjadi ciri-ciri individu manusia yang bersangkutan. Sukmadji (2010) menambahkan bahwa di Indonesia tidak kurang terdapat 316 suku bangsa. Dengan berbagai faktor pendorongnya, interaksi dari begitu banyak suku bangsa itu dapat berjalan baik. Namun demikian gambaran sosial yang ada pada era sekarang adalah jauh sekali dengan budaya Bangsa Indonesia sebagai bangsa timur yang telah memiliki potensi yang besar sebagai bangsa yang santun. Diduga bahwa faktor lingkunganlah yang telah menjadi pendorong terjadinya situasi itu.
Berbagai pemikiran tersebut dinilai cukup banyak memberikan dasar berpijak perlunya secara akademik mencoba melihat kembali ciri-ciri manusia Indonesia saat ini, dengan dasar berpijak pada pemikiran Lubis diatas, didukung oleh berbagai indikasi gambaran ciri-ciri manusia Indonesia yang tersebut diatas.

Setelah waktu berjalan lebih dari 30 tahun sejak Lubis mengemukakan pendapatnya, terjadi berbagai perubahan dan perkembangan di Indonesia maupun di tataran global. Adanya perubahan dan perkembangan mendasar dalam bidang $3 \mathrm{~T}$ (teknologi, transportasi, dan telekomunikasi) telah banyak mempengaruhi kehidupan masyarakat, baik dalam pola hidup sehari-hari, maupun dalam berperilaku. Dalam selang waktu tersebut, telah terjadi pergantian pimpinan negara sebanyak 4 kali, terjadi perubahan struktur penyelenggara negara, perkembangan interaksi dan komunikasi global-regional-lokal yang begitu intensif, dilansirnya berbagai tujuan menyangkut sumberdaya manusia melalui MDGs, keharusan alokasi anggaran untuk Pendidikan sebesar 20 persen, perhatian makin besar pada gender dan perlindungan anak, serta pindahnya penanganan kebudayaan dari Kementrian Pendidikan ke Kementerian Pariwisata, adalah beberapa dari perubahan mendasar tersebut.

Pertanyaan yang kemudian muncul adalah dengan adanya berbagai 
perkembangan tersebut, apakah kemudian terjadi pula perubahan dalam karakteristik atau ciri-ciri manusia Indonesia, apakah ciri-ciri manusia Indonesia seperti yang dikemukakan oleh Lubis betul adanya ataukah terjadi perubahan ciri-ciri dalam pandangan manusia Indonesia sendiri. Pertanyaan-pertanyaan itu yang dicoba dijawab dengan kajian ini, dengan fokus pada aspek-aspek yang menyangkut manusia Indonesia yang terkait dengan bidang penyuluhan perikanan. Diharapakan kajian dapat menjadi pemikiran untuk langkah-langkah pengembangan sumberdaya manusia Indonesia dimasa depan, terutama yang terkait dengan aktivitas penyuluhan perikanan.

Waktu Pelaksanaan Kajian

Kajian dilaksanakan pada Februari Mei 2010.

\section{Responden}

Responden kajian ini dipilih secara purposif, terdiri dari taruna Jurusan Penyuluhan Sekolah Tinggi Perikanan Tingkat Remaja (I) sebanyak 70 orang, dan Tingkat Utama (IV) sebanyak 68 orang. Taruna Utama dipilih untuk mewakili taruna yang sudah dianggap senior, sehingga dinilai telah memiliki bekal yang memadai untuk mengemukakan pendapat dengan lebih matang dan terbuka. Taruna Remaja dipilih untuk mewakili taruna yang baru saja masuk ke dunia pendidikan tinggi, sehingga dinilai masih banyak didominasi oleh pemikiran masa remaja mereka, namun telah cukup memiliki bekal untuk dapat menilai perkembangan yang terjadi pada kehidupan masyarakat secara umum.

Agar diperoleh gambaran yang lebih menyeluruh mengenai Ciri-ciri manusia Indonesia, maka dipilih sebanyak 31 responden Penyuluh Perikanan yang mengikuti Pelatihan Penjenjangan tenaga Fungsional Penyuluh Perikanan pada bulan Maret 2010. Dengan demikian hasil yang diperoleh diharapkan dapat mewakili mereka yang sedang bergerak dibidang Penyuluhan Perikanan, baik yang sedang mengikuti pendidikan maupun yang telah berada di lapangan untuk melaksanakan kegiatan penyuluhan perikanan.

\section{Kuesioner}

Kuesioner disusun dengan asumsi bahwa responden belum secara eksplisit mengetahui pemikiran Lubis mengenai ciri-ciri manusia Indonesia. Terdapat 30 (tiga puluh) pilihan jawaban mengenai pendapat responden tentang ciri-ciri manusia Indonesia pada saat kajian dilaksanakan. Pilihan jawaban semuanya diambil dari ciri-ciri atau sifat-sifat yang disebutkan secara eksplisit dalam buku Lubis (2008).

Agar tidak secara tegas dibedakan antara sifat yag berkonotasi positif dengan sifat yang berkonotasi negatif, pertanyaan 
disusun menurut abjad dari huruf pertama sifat-sifat tersebut. Responden diminta untuk memilih 10 (sepuluh) ciri yang menurut responden paling dominan menjadi penciri manusia Indonesia saat ini. Pilihan ciri-ciri tersebut adalah sebagai berikut:

Tabel 2. Pilihan Ciri-ciri Manusia Indonesia, 2010

1. Artistik

2. Berani mengatakan yang benar

3. Brutal

4. Dapat dipercaya

5. Enggan bertanggungjawab

6. Feodal

7. Ingkar janji

8. J u j u r

9. Ksatria

10. Lemah karakter

11. Lemah lembut

12. Menyerah pada nasib

13. Mudah putus asa

14. M u n a f i k

15. Pandai membawakan diri
16. $\mathrm{P}$ e $\mathrm{m}$ a l u

17. $\mathrm{P}$ e $\mathrm{m}$ a r a h

18. Penuh perhitungan

19. Percaya takhyul

20. Rajin bekerja

21. $\mathrm{R}$ a $\mathrm{m}$ a h

22. $\mathrm{S}$ a b a r

23. S o p a n

24. Taat beribadah

25. Teliti

26. Tidak bisa mengambil keputusan cepat

27. Tidak jujur

28. Tidak punya pendirian

29. To le r a n

30. U l e t

\section{Analisis Data}

Data yang terkumpul ditabulasikan dan dianalisis secara deskriptif kuantitatif berdasarkan kelompok jawaban responden yang diperoleh. Untuk dapat memperoleh variasi jawaban pada masing-masing kelompok responden (Utama, Remaja, dan Penyuluh), pada masing-masing kelompok dibedakan atas 3 (tiga) kelompok etnis secara geografis, yaitu etnis suku di Sumatra, Jawa, dan Indonesia Timur. Diharapkan dengan demikian dapat diperoleh deskripsi pendapat per kelompok etnis, walaupun disadari bahwa pengelompokan tersebut memang terlalu besar. Keterbatasan jumlah responden menjadi alasan utama atas 3 kelompok etnis tersebut. Pada responden taruna Remaja dicoba untuk memisahkan etnis Jawa dengan etnis Sunda, karena jumlah responden dinilai cukup untuk memisahkan keduanya.

Pada masing-masing kelompok responden diidentifikasi ciri-ciri yang sama sekali tidak dipilih oleh responden. Hal ini dilakukan untuk mengetahui penilaian responden terdahap ciri-ciri yang dinilai BUKAN mencerminkan ciri-ciri manusia Indonesia. Analisis kemudian dilakukan untuk data yang menggabungkan jawaban dari ketiga kelompok responden. 
HASIL DAN PEMBAHASAN

\section{Responden Taruna Remaja}

Taruna Remaja pada saat kajian dilaksanakan masih dalam periode mengikuti Masa Basis Pendidikan di Sekolah Tinggi Perikanan (STP) untuk menanamkan sosialisasi norma dan tata nilai kehidupan dalam lingkup STP. Mata Kuliah yang terkait dengan telaahan tentang aspek-aspek sumberdaya manusia adalah Sosiologi Perikanan dan Psikologi Sosial. Dengan bekal mata kuliah formal yang masih terbatas tersebut, kelompok in dinilai masih terbatas pemahaman mereka tentang manusia Indonesia. Namun demikian, bekal pengetahuan yang telah mereka peroleh semasa di Sekolah Lanjutan Tingkat Atas dinilai sudah cukup memadai untuk dapat memberikan penilaian tentang ciri-ciri manusia Indonesia.

Dengan pemahaman yang ada pada para Taruna Remaja, hasil analisis menunjukkan bahwa 11 (sebelas) ciri manusia Indonesia yang dominan menurut versi mereka adalah: (1) Enggan Bertanggungjawab, (2) Brutal, (3) Tidak Dapat Mengambil Keputusan Cepat, (4)
Janji, (7) Penuh Perhitungan, (8) Tidak Punya Pendirian, (9) Tidak Jujur, (10) Menyerah Pada Nasib, dan (11) Munafik (Tabel 3). Secara total tidak ada ciri yang tidak dipilih satupun oleh responden Taruna Remaja.

Terdapat variasi dalam urutan ciri-ciri itu menurut kelompok Etnis pada taruna Remaja ini. Dengan mengacu pada pendapat Lubis yang menekankan 6 ciri utama manusia Indonesia, maka 6 ciri menurut taruna Remaja dari Sumatra adalah enggan Bertanggungjawab, Percaya Takhyul, Brutal, Artistik, Tidak Jujur, dan Munafik. Urutan menurut taruna Remaja dari Jawa adalah: brutal, percaya takhyul, enggan bertanggungjawab, tidak bisa mengambil keputusan cepat, tidak punya pendirian, dan tidak jujur. Dalam pada itu, urutan ciri menurut taruna remaja dari Indonesia Timur adalah: artistik, penuh perhitungan, enggan bertanggungjawab, tidak punya pendirian, brutal dan ingkar janji. Tampak bahwa ada indikasi taruna dari Indonesia Timur lebih "lunak" daripada taruna dari Sumatra dan Jawa dalam memberikan penilaian tentang ciri-ciri manusia Indonesia. artistik, (5) Percaya Takhyul, (6) Ingkar

Tabel 3. 11 Ciri-ciri Dominan Manusia Indonesia (Versi Taruna Remaja, 2010)

\begin{tabular}{|c|c|c|c|c|c|c|}
\hline No & Deskrisi & Sumatra & Jawa & TIMUR & \multicolumn{2}{|c|}{ Total } \\
\hline 1. & Enggan bertanggungjawab & 20 & 14 & 16 & 50 & $(7,1)$ \\
\hline 2. & Brutal & 16 & 16 & 14 & 46 & $(6,6)$ \\
\hline 3. & Tdk bisa mengambil kepts. cepat & 13 & 20 & 13 & 46 & $(6,6)$ \\
\hline
\end{tabular}




\begin{tabular}{|c|l|c|c|c|cc|}
\hline 4. & A r t i s t i k & 15 & 9 & 20 & 44 & $(6,2)$ \\
5. & Percaya Takhayul & 17 & 15 & 9 & 41 & $(5,9)$ \\
6. & Ingkar janji & 14 & 12 & 14 & 40 & $(5,6)$ \\
7. & Penuh perhitungan & 11 & 11 & 18 & 40 & $(5,6)$ \\
8. & Tidak punya pendirian & 12 & 13 & 15 & 40 & $(5,6)$ \\
9. & Tidak jujur & 13 & 13 & 12 & 38 & $(5,3)$ \\
10 & Menyerah pada nasib & 12 & 12 & 12 & 36 & $(5,2)$ \\
11. & Munafik & 14 & 8 & 13 & 35 & $(5,1)$ \\
12 & Lain-lain (19 ciri) & 103 & 67 & 74 & 244 & $(34,9)$ \\
\hline & & 260 & 210 & 230 & 700 & $(100)$ \\
\hline
\end{tabular}

\section{Taruna Utama}

Dinilai bahwa taruna Utama lebih matang dalam memberikan penilaian daripada taruna Remaja, mengingat mereka hampir menyelesaikan kuliahnya. Dengan demikian diharapkan lebih dapat memberikan penilaian yang makin realistik dan beralasan. Dengan pemahaman yang ada pada para Taruna Utama tersebut, 11 (sebelas) ciri manusia Indonesia yang dominan menurut versi para taruna Utama tersebut adalah: (1) Brutal, (2) Percaya Takhyul, (3) Tidak bisa Mengambil Keputusan Cepat, Mudah Putus Asa, (5) Enggan Bertanggungjawab, (6) Artistik, (7) Lemah Karakter, (8) Menyerah pada Nasib, (9) Tidak Punya Pendirian, (10) Ingkar Janji, dan terakhir (11) munafik (Tabel 4). Terdapat satu ciri yang tidak satupun responden memilihnya, yaitu ciri Ksatria.

Sama halnya dengan taruna Remaja, terdapat variasi dalam urutan ciri-ciri itu menurut kelompok Etnis pada taruna Utama; 6 ciri menurut taruna Utama dari Sumatra adalah Brutal, Percaya Takhyul, Tidak Bisa Mengambil Keputusan Cepat, Mudah Putus Asa, Lemah Karakter, dan Enggan Bertanggungjawab. Urutan menurut taruna Utama dari Jawa (termasuk Sunda) adalah: brutal, percaya takhyul, tidak bisa mengambil keputusan cepat, mudah putus asa, enggan bertanggungjawab, dan artistik. Dalam pada itu, urutan ciri menurut taruna Utama dari Indonesia Timur adalah: Mudah Putus Asa, Brutal, Percaya Takhyul, Tidak bisa Mengambil Keputusan Cepat, tidak punya pendirian, dan artistik. Disini tidak terlalu berbeda persepsi dari ketiga asal etnis Taruna.

\section{Penyuluh Perikanan}

Kelompok Responden yang dinilai paling matang pemikirannya adalah kelompok Penyuluh Perikanan. Pengalaman lapangan diduga akan mendorong responden Penyuluh Perikanan berhati-hati dalam menentukan pilihan jawaban. Dengan pemahaman yang ada pada para Penyuluh Perikanan tersebut, 11 (sebelas) ciri manusia Indonesia yang dominan menurut versi responden Penyuluh adalah: (1) Ramah, (2) artistik, (3) sopan, (4) taat beribadah, (5) berani mengatakan yang benar, (6) jujur, (7) lemah lembut, (8) pandai membawakan diri, (9) Rajin Bekerja, (10) Sabar, (11) Tidak Bisa Mengambil Keputusan Cepat, dan (12) Toleran. (Tabel 5). Sama halnya dengan Taruna Utama, ciri Ksatria tidak dipilih satupun oleh responden Penyuluh. 
Tabel 4. 11 Ciri-ciri Dominan Manusia Indonesia (Versi Taruna Utama, 2010)

\begin{tabular}{|l|l|c|c|c|c|c|}
\hline No & \multicolumn{1}{|c|}{ Deskrisi } & Sumatra & Jawa & Sunda & TIMUR & Total \\
\hline & & & & & & \\
1. & B r u t a l & 11 & 12 & 13 & 10 & $46(6,8)$ \\
2. & Percaya Takhyul & 11 & 16 & 8 & 9 & $44(6,5)$ \\
3. & Tdk bisa mengambil kepts. cepat & 11 & 12 & 10 & 9 & $42(6,2)$ \\
4. & Mudah putus asa & 11 & 10 & 9 & 11 & $41(6,0)$ \\
$\mathbf{5 .}$ & Enggan bertanggungjawab & 8 & 11 & 11 & 7 & $37(5,4)$ \\
$\mathbf{6 .}$ & A r t i s t i k & 7 & 12 & 8 & 8 & $35(5,1)$ \\
7. & Lemah Karakter & 10 & 9 & 8 & 8 & $35(5,1)$ \\
$\mathbf{8 .}$ & Menyerah pada nasib & 8 & 12 & 8 & 7 & $35(5,1)$ \\
$\mathbf{9 .}$ & Tidak punya pendirian & 8 & 9 & 9 & 9 & $35(5,1)$ \\
$\mathbf{1 0}$ & Ingkar janji & 5 & 10 & 9 & 5 & $29(4,3)$ \\
$\mathbf{1 1 .}$ & Munafik & 5 & 9 & 9 & 6 & $29(4,3)$ \\
$\mathbf{1 2}$ & Lain-lain (19 ciri) & 75 & 78 & 68 & 71 & $272(40,0)$ \\
\hline & T o t a l & 170 & 200 & 150 & 160 & $680(100)$ \\
\hline
\end{tabular}

Meski terdapat variasi penilaian responden berdasarkan kelompok etnis seperti halnya dengan kelompok responden taruna, namun meningat jumlah responden yang relatif kecil untuk kelompok Etnis Sumatra dan Jawa, maka variasi in dinilai dapat diabaikan. Hal menarik yang muncul dari penilaian para penyuluh in adalah bahwa hampir seluruh ciri-ciri yang dipilih adalah ciri-ciri yang positif, kecuali 1 (satu) ciri, yaitu Tidak Bisa Mengambil Keputusan Cepat.

Pilihan in sangat jelas berbeda dengan pilihan para responden Taruna, baik Remaja maupun Utama, yang cenderung memilih ciri-ciri yang bernuansa negatif. Diduga hal in berkaitan dengan 2 hal: (1) para penyuluh memang menemui bahwa ciri-ciri yang cenderung positif tersebut benar-benar mereka temui dalam masyarakat di lingkungan tugas dan kerja mereka, maupun dalam kehidupan mereka sehari-hari di tempat kerjanya; (2) para penyuluh yang terpilih sebagai responden tidak mencerminkan representasi dari para penyuluh secara keseluruhan, mengingat jumlahnya yang relatif sedikit (31 orang) yang mewakili 3 kelompok etnis, dimana kelompok etnis Indonesia Timur mendominasi kelompok penyuluh ini (17 orang). Namun demikian hal in merupakan temuan yang menarik, bukan saja karena pilihan mereka yang cenderung berseberangan dengan pilihan para taruna, namun juga secara metodologis menunjuk pada peluang terjadinya ketidak-terwakilan (under-representedness) dari responden penyuluh.

\section{Analisis Gabungan Responden}

Penggabungan analisis dari ketiga kelompok responden dimaksudkan untuk menghilangkan pengaruh dari kelompok responden terhadap hasil pilihan mereka atas ciri-ciri manusia Indonesia. Pada saat yang sama hal ini dapat memberikan gambaran bagaimana persepsi responden secara keseluruhan dalam menanggapi pertanyaan tentang ciri-ciri manusia Indonesia. 
Tabel 5. 12 Ciri-ciri Dominan Manusia Indonesia (Versi Penyuluh, 2010)

\begin{tabular}{|c|l|c|c|c|cc|}
\hline No & \multicolumn{1}{|c|}{ Deskrisi } & Sumatra & Jawa + & TIMUR & \multicolumn{2}{|c|}{ Total } \\
\hline & & & & & & \\
1. & Ramah & 5 & 5 & 12 & 22 & $(7,1)$ \\
2. & artistik & 5 & 4 & 11 & 20 & $(6,5)$ \\
3. & sopan & 3 & 4 & 13 & 20 & $(6,5)$ \\
4. & taat beribadah & 4 & 4 & 10 & 18 & $(5,8)$ \\
5. & berani mengatakan yang benar & 6 & 2 & 5 & 13 & $(4,2)$ \\
6. & jujur & 3 & 2 & 8 & 13 & $(4,2)$ \\
7. & lemah lembut & 1 & 3 & 9 & 13 & $(4,2)$ \\
8. & pandai membawakan diri & 4 & 3 & 6 & 13 & $(4,2)$ \\
9. & rajin bekerja & 3 & 3 & 7 & 13 & $(4,2)$ \\
10 & sabar & 3 & 2 & 8 & 13 & $(4,2)$ \\
11. & tdk bisa mengambil kpts. cepat & 3 & 4 & 6 & 13 & $(4,2)$ \\
12 & toleran & 4 & 3 & 6 & 13 & $(4,2)$ \\
13. & Lain-lain (18 ciri) & 16 & 41 & 69 & 126 & $(40,6)$ \\
& & 60 & 80 & 170 & $310 \quad(100)$ \\
& T o t a l & & & & & \\
\hline
\end{tabular}

Keterangan: Etnis Jawa digabung dengan etnis Sunda karena jumlahnya terbatas.

Dalam analisis Gabungan, 11 (sebelas) ciri manusia Indonesia yang dominan adalah: (1) Brutal, (2) Tidak Bisa Mengambil Keputusan Cepat, (3) Artistik, (4) Percaya Takhyul, (5) Enggan Bertanggungjawab, (6) Tidak Punya Pendirian, (7) Mudah Putus Asa, (8) Ingkar Janji (9) Tidak jujur, (10) Menyerah pada Nasib, dan (11) Munafik (Tabel 6). Tampak bahwa dengan analisis Gabungan in, masalah ketidak-terwakilan dari kelompok Punyuluh dinilai dapat terjawab, hanya ciri “Tidak Bisa Mengambil Keputusan Cepat” yang muncul kembali; penciri positif yang mendominasi tanggapan para penyuluh tidak satupun yang muncul kembali dalam analisis Gabungan. Untuk mendapatkan gambaran lengkap untuk merbandingkan ciri-ciri dominan yang dipilih oleh responden, pada Tabel Lampiran 1 disajikan ciri-ciri dominan per kelompok rsponden.

\section{Pembahasan}

Dari sisi upaya untuk lebih memberikan bobot akademik terhadap ciri-ciri Manusia Indonesia seperti yang dinyatakan oleh Mochtar Lubis pada tahun 1977, kajian telah berhasil menunjukkan dukungan akademik tersebut dengan menyajikan ciri-ciri yang didasarkan suatu penelitian formal. Hasil kajian yang diperoleh menunjukkan hasil bahwa ada kecenderungan pergeseran ciri-ciri dari yang telah diindikasikan oleh Lubis.

Tabel 6. Ciri-ciri Manusia Indonesia (Versi Gabungan, 2010)

\begin{tabular}{|l|l|c|c|c|c|}
\hline No & \multicolumn{1}{|c|}{ Deskrisi } & Sumatra & Jawa & TIMUR & Total \\
\hline & & & & & \\
1. & B r u t a l & 30 & 43 & 30 & $103(6,1)$ \\
2. & Tdk bisa mengambil kepts. cepat & 33 & 41 & 28 & $102(6,0)$ \\
\hline
\end{tabular}




\begin{tabular}{|c|l|c|c|c|c|}
\hline 3. & A r t i s t i k & 28 & 32 & 39 & $99(5,9)$ \\
4. & Percaya Takhayul & 26 & 47 & 24 & $97(5,7)$ \\
5. & Enggan bertanggungjawab & 31 & 38 & 27 & $96(5,7)$ \\
6. & Tidak punya pendirian & 23 & 33 & 27 & $83(4,9)$ \\
7. & Mudah putus asa & 21 & 33 & 25 & $79(4,7)$ \\
8. & Ingkar janji & 23 & 30 & 25 & $78(4,6)$ \\
9. & Tidak Jujur & 22 & 31 & 23 & $76(4,5)$ \\
10 & Menyerah pada nasib & 20 & 34 & 21 & $75(4,4)$ \\
11. & Munafik & 23 & 26 & 24 & $73(4,3)$ \\
12 & Lain-lain (19 ciri) & 390 & 62 & 267 & $729(43,1)$ \\
\hline & T o t a l & 670 & 460 & 560 & $1690(100)$ \\
& & & & & \\
\hline
\end{tabular}

Meski keterwakilan responden diakui dapat dipertanyakan kecukupannya, namun kajian setidaknya menunjukkan bahwa kecenderungan pergeseran itu telah terjadi. Kecenderungan pergeseran ciri ternyata tidak bergerak dari ciri-ciri yang cenderung negatif menjadi ciri-ciri yang cenderung positif, melainkan bergeser dari kelompok ciri-ciri negatif “versi” Lubis kepada kelompok ciri-ciri negatif yang lainnya. 6 (enam) ciri-ciri yang dikemukakan oleh Lubis adalah Munafik atau hipokrit, enggan dan segan bertangggungjawab atas perbuatannya, bersikap dan berperilaku feodal, percaya takhyul, artistik, dan lemah watak atau karakternya, tanpa menyebutkan uturan dominasi ciri-ciri tersebut. Hasil kajian menunjukkan bahwa urutan 11 (sebelas) ciri-ciri yang dominan secara kuantitatif adalah Brutal, Tidak Bisa Mengambil Keputusan Cepat, Artistik, Percaya Takhyul, Enggan Bertanggungjawab, diantara mereka yang mimilih ciri Ksatria. Tidak Punya Pendirian, Mudah Putus Asa,

Ingkar Janji, Tidak jujur, Menyerah pada Nasib, dan Munafik. Dengan demikian apabila hanya 6 urutan teratas yang digunakan, terdapat 3 (tiga) ciri lama ( munafik, feodal, dan berwatak lemah) yang digantikan oleh ciri-ciri yang baru (brutal, tidak cepat mengambil keputusan, dan tidak mempunyai pendirian).

Munculnya ciri Brutal cukup mengagetkan, apalagi ciri itu berada dalam urutan teratas. Pengamatan responden terhadap kejadian-kejadian yang disebarkan media masa, maupun pengamatan terhadap apa yang terjadi disekitarnya diduga menjadi penyebab munculnya ciri baru ini. Dengan demikian dapat dikatakan bahwa kemajuan dalam teknologi dan telekomunikasi telah ikut mendorong terjadinya pergeseran ciri-ciri manusia Indonesia. Ditemukan juga bahwa pada kelompok Taruna Utama dan kelompok responden Penyuluh, tak satupun 
Hal in nampak sejalan dengan munculnya ciri Brutal tersebut.

Meskipun memiliki kelemahan dalam jumlah, hasil analisis untuk kelompok Penyuluh perlu diperhatikan dengan baik. Hasil yang cenderung positif dari para penyuluh menunjukkan bahwa meskipun dalam skala yang terbatas, masih ada bagian kelompok masyarakat yang melihat sisi-sisi positif dari ciri manusia Indonesia. Hal in sejalan dengan pendapat Lubis yang masih menunjuk adanya ciri-ciri manusia Indonesia yang positif, meski tidak terlalu nyata ditekankan oleh Lubis.

Diperlukan upaya-upaya khusus untuk dapat membawa kembali citra positif dari manusia Indonesia. Kesantunan dan keramahtamahan manusia Indonesia yang seolah memudar pada masa-masa sekarang nampaknya memang harus terus diupayakan kembali (Sukmadji, 2010). Hal ini tentu saja memerlukan upaya dari semua pihak secara integratif untuk dapat mengupayakannya. Namun hal ini disadari memang bukan upaya yang mudah. Adanya fenomena unmet need (keinginan berpartisipasi yang tidak dapat dipenuhi) dalam kaitannya dengan pelaksanaan program Keluarga Berencana (Harijono, 2010) misalnya, menunjukkan bahwa keinginan warga Indonesia untuk memperbaiki diri melalui program KB ternyata tidak selamanya dapat dipenuhi, karena ketidak-siapan pelayanan dari yang berwenang untuk memberikan pelayanan itu.
Hal ini apabila terjadi secara berulang, dan mencakup berbagai bidang kehidupan manusia Indonesia, akan berdampak negatif bagi upaya untuk mengangkat kembali harkat dan nilai-nilai luhur yanng dikenal sebagai penciri manusia Indonesia pada masa-masa yang "lalu”.

Responden terkait erat dengan aktivitas Penyuluhan Perikanan. Hasil kajian menegaskan bahwa dalam melaksanakan aktivitas penyuluhan, para penyuluh benar-benar harus memahami karakteristik mitra penyuluhannya agar dapat diperoleh hasil penyuluhan yang efektif. Kegagalan dalam mengidentifikasi karakteristik mitra penyuluhan dapat berakibat fatal, terutama apabila para penyuluh ternyata salah dalam mengidentifikasi ciri-ciri yang bersifat negatif. Bagi penyuluh yang telah lama bertugas di lokasi yang sama, seyogyanya telah dapat menyusun metoda dan strategi penyuluhan yang benar-benar sesuai dengan karakteristik mitra kerja penyuluhan di lokasi kerjanya. Bagi penyuluh yang baru bertugas, maka menjadi kewajibannya untuk terlebih dahulu mendalami ciri atau karakteristik calon mitra kerjanya, untuk kemudian menyusun program dan rencana penyuluhan yang sesuai.

Dalam hal ini Pranadji (2003) menyatakan bahwa SDM penggerak usaha pertanian dan pedesaan, dimana penyuluh perikanan adalah bagian dari SDM penggerak 
itu, haruslah mampu memahami aspek bertangggungjawab atas perbuatannya, sosio-budaya kelompok mitranya agar dapat berperilaku feodal, percaya takhyul, artistik, melaksanakan kegiatannya dengan baik. dan lemah karakternya. Meskipun Lubis Dalam terminologi van den Ban dan Hawkins mencoba untuk juga menyebut ciri-ciri yang (1999), para penyuluh haruslah mampu bersifat positif, namun penekanan Lubis lebih mengangkat citra ideal manusia dan kepada ciri-ciri diatas.

masyarakat, melalui penghargaan terhadap

Setelah mengalami perjalanan norma dan tata nilai yang berlaku setempat. kehidupan manusia Indonesia lebih dari 30 Ciri-ciri manusia komponen masyarakat yang bersangkutan jelas diwarnai oleh norma dan tata nilai yang berlaku setempat tersebut. Secara rinci Nasution dkk (2007) mengindikasikan bahwa untuk masyarakat perikanan, terutama nelayan, perlu tahun sejak Lubis mengemukakan pendapatnya, ternyata ciri-ciri manusia Indonesia tetap diindikasikan negatif, meskipun bergerak pada ciri-ciri negatif yang berbeda, yaitu Brutal, Tidak Bisa Mengambil diperhatikan dimensi-dimensi pengetahuan lokal, sistem relegi, ekonomi, kelembagaan, dan politik untuk dapat memahami kehidupan keseharian mereka. Menunjuk pada pendapat-pendapat itu, digabungkan dengan hasil yang diperoleh dari kajian ini, maka ciri-ciri yang melekat secara individual maupun secara kelompok mitra kerja penyuluhan, baik yang positif maupun terutama yang negatif, dengan demikian menjadi perlu untuk terus diperhatikan dan diikuti perkembangannya dalam pelaksanaan kegiatan penyuluhan perikanan.

\section{KESIMPULAN}

Ditengah upaya meningkatkan citra bangsa Indonesia di percaturan dunia, masyarakat dikejutkan oleh pernyataan Lubis pada tahun 1977 bahwa manusia Indonesia adalah manusia yang Munafik, enggan 
bahkan telah hilang dari kehidupan manusia Indonesia akhir-akhir ini.

Diperlukan upaya-upaya khusus untuk dapat mengembalikan ciri-ciri manusia Indonesia yang lebih bersifat positif. Ciri-ciri yang bernuansa kesopanan dan kesantunan dinilai perlu diprioritaskan untuk dapat kembali menjadi ciri manusia Indonesia.

Kegiatan Penyuluhan Perikanan sangat terkait dengan pentingnya memahami ciri-ciri manusia Indonesia, sehingga pihak-pihak yang terkibat didalamnya dapat mnyiapkan diri dengan baik. Para penyuluh perlu menyiapkan strategi dan program penyuluhan yang sesuai dengan ciri-ciri, norma, ataupun tatanilai mitra penyuluhannya, sementara para pitra penyuluhan dapat secara terencana berupaya untuk mengubah dan memperbaiki diri, sehingga kedua belah pihak dapat saling mengakui dan menghargai situasi, kondisi, serta apa-apa yang ada pada mereka masing-masing demi kebaikan interaksi diantara keduanya.

\section{DAFTAR PUSTAKA}

Harijono, Try. 2010. Wajah Manusia Hilang dalam Angka. Kompas, 8 Juni 2010.

Husaini, Adian. Manusia Indonesia. 2010. http://www.insistnet.view $=$ article\&id =179: manusiaindonesia\&catid=23:pendidi $\mathrm{k}$ anislm
Januar, Puguh Gita. 2010. Perkembangan Biologis Manusia Indonesia.

http://edukasi.kompasiana.com/2010/ 10/21/perkembangan-biologis-manusia-indo nesia/

Lubis, Mochtar. 2008. Manusia Indonesia: Sebuah Pertanggung jawaban. Yayasan Obor Indonesia. Jakarta.

Nasution, Zahri dkk. 2007. Sosial Budaya Masyarakat Nelayan: Konsep dan Indikator Pemberdayaan. BRKP DKP. Jakarta.

Noer, Khayun Achmad. 2010. Manusia Indonesia Seutuhnya. http://id.shvoong.com/humanities/1706 680-manusia-indonesia-seutuhnya/

Pranadji, Tri. 2003. Menuju Transformasi Kelembagaan dalam Pembangunan Pertanian dan Pedesaan. PSE. Bogor.

Setiawan, Asep. 2008. Memperkuat Kualitas Manusia Indonesia. http://www.asepsetiawan.com/archives 1450

Sen, Amartya. 2005. The Argumrntative Indian. Penguin Books. Landon.

Sukmadji, Bambang. 2010. Menjadi Manusia Indonesia yang Kembali Santun.

http://agupenajateng.net/2010/03/14/ menjadi-manusia-indonesia-yang-kemba li-santun/

Suparno, Erman. 2007. Pradigma Baru Transmigrasi: Menuju Kemakmuran Rakyat. Depnakertrans. Jakarta. 
Sutanto, Yusuf. 2007. Kearifan Timur United Nations. 2010. The Millennium dalam Etos Kerja dan Seni Devepment Goals Report 2010. New Memimpin. Penerbit Buku Kompas. York.

Jakarta. 